\title{
Effects of E-Banking Adoption on the Financial Performance of State-Owned Commercial Banks in Bangladesh
}

Md. Imran Hossain, University of Rajshahi, Bangladesh

\begin{abstract}
This study examines the relationship between e-banking adoption and the financial performance of state-owned commercial banks in Bangladesh. The pooled ordinary least square (OLS) estimate was applied to analyze the panel data of the sample banks. The empirical findings reveal that e-banking adoption and implementation has a significant negative impact on banks' profitability in terms of return on assets, return on equity, and net interest margin in the year of adoption. However, the result also shows that e-banking has a significant positive impact on return on assets in the year following adoption.
\end{abstract}

\section{KEYWORDS}

Bangladesh, Disaster Recovery Sites, E-Banking, Firm Performance, Information Communication Technology, Online Core Banking Solutions, Ordinary Least Square, Panel Data, State-Owned Commercial Banks

\section{INTRODUCTION}

Over the past decades, the incredible development in information communication technology (ICT) has expanded the door of opportunities (Chege et al., 2020; Hsu et al., 2020) and changed business environments around the world (Sivathanu, 2019; Ananth \& Singh, 2016). The literature (AlOmoush et al., 2020; Al-Swidi \& Al-Hosam, 2012) suggests that ICT-based operations and service offerings are crucial for an efficient business strategy and, therefore, information communication technology (ICT)-enabled banking operations should be adopted and implemented in banks to ensure sustainable growth of the banking sector (Al-Omoush et al., 2020). To keep pace with the modernization of organizations, the banking sector has also embraced the development in innovation and its implementation that led to the transformation of banking operations from a manual system to a technology-based digital banking system around the world (Aduda \& Kingoo, 2012). As a result, ICT-based banking operations, popularly known as electronic banking or e-banking (Salehi \& Alipour, 2010), are being considered as the heart of the banking sector in the contemporary banking world (Al-Omoush et al., 2020; Aliyu \& Tasmin, 2012).

The concept of digital banking or electronic banking (e-banking) is a relatively new practice in Bangladesh, since the technology infrastructural development is still under development. In Bangladesh, the banks began implementing electronic banking systems in 2001 (Rahman, 2007). Before that time, the banking sector was operated completely under the analog system

DOI: 10.4018/IRMJ.20211001.oa1

This article published as an Open Access article distributed under the terms of the Creative Commons Attribution License (http://creativecommons.org/licenses/by/4.0/) which permits unrestricted use, distribution, and production in any medium, provided the author of the original work and original publication source are properly credited. 
(Siddik et al., 2016) where all bank transactions and activities were accomplished manually, which was time-consuming, tiresome, and required a significant workforce to carry out the operations. In fact, Bangladesh was behind in taking advantage of the enormous opportunities that has arisen from technology-based business operations such as e-commerce and e-business (Ahmed \& Islam, 2008). However, the banks in Bangladesh, both the private and public (state-owned) sector banks, have started adopting ICT-based e-banking operations in the last few years (Hasan et al., 2010). Past studies revealed that various exogenous and endogenous factors, for example, customer retention, better service offerings, and overall performance improvement, led the organizations to adopt and utilize the technology (Hosain \& Azam, 2019; Azam, 2014). Kondabagil (2007) also opined that not unlik other organizations, the e-banking adoption decision of the banks are determined by perceived benefits (for example, improved performance, customer retention, competitive costs, etc.) of the systems. Therefore, it is crucial to measure the bank's performance under the adoption of e-banking to monitor the actual and potential progress of existing and potential adopters of e-banking systems since the improved performance enhances the likelihood of organizations' technology adoption decisions (Azam, 2014).

Commercial banks play a crucial role in the emerging economies more than that of developed economies and, therefore, studying the progress of commercial bank performance has attracted the bulk of researchers' attention (Gafoor et al., 2018; Siddik et al., 2016) from an emerging economy perspective. The attributes, operational practices, and performance of financial markets and banking systems significantly differ from developed economies to developing economies. For example, developed economies encompass strong and sound financial markets and banking systems, whereas developing economies posit undersized and inefficient financial markets and banking systems (Siddik et al., 2016).

There is little evidence focusing on technology-based banking system adoption, utilization, and effects thereafter in the context of Bangladesh (Hasan et al., 2010; Al-Amin \& Rahman, 2010; Ashraf et al., 2020; Rahman et al., 2020; Jahan et al., 2020). Hasan et al. (2010) studied the benefits and barriers of e-banking adoption from Bangladesh perspective, whereas Al-Amin and Rahman (2010) documented that strong internal network, developed IT infrastructure, and country domain, determines the electronic banking adoption and utilization decision. On the other hand, Jahan et al. (2020) examined the determinants of customer satisfaction under Internet banking operations in Bangladesh. The extensive literature review documented that Siddik et al. (2016) evaluated the impact of e-banking activities on Bangladeshi private commercial banks.

However, an extensive literature review revealed that there is no evidence addressing the examination of e-banking adoption effects on the state-owned commercial banks' financial performance in Bangladesh thus far. Therefore, to address this research gap, the current study attempts to empirically investigate the impact of electronic banking adoption on state-owned commercial banks' financial performance in Bangladesh. The study has used the data from four state-owned commercial banks in Bangladesh that have adopted the e-banking system over the period of 2009 to 2018.

The current study contributes to the extant literature by complying with (or otherwise) the empirical findings of prior studies that examined e-banking effects on the financial performance of commercial banks. More particularly, this study makes a unique contribution to the existing e-banking literature by addressing the state-owned commercial bank perspective from within a developing country context. Therefore, the empirical estimate of the study and the result thereof has a greater impact on the emerging economies by drawing policymakers and bank managements' attention to pursuing, adopting, and meaningfully implementing the e-banking systems in a wider range for robust growth in the banking industry. 


\section{LITERATURE REVIEW}

\section{The E-Banking Concept}

E-banking encompasses all the Internet-driven banking services provided online to bank customers (Daniel, 1999). E-banking allows bankers, customers, and other stakeholders online access to their bank accounts to perform transactions and obtain financial products and services-related information (Siddik et al., 2016; Bauer et al. 2005). Therefore, e-banking enables customers to perform banking activities such as accessing their accounts, fund transfers, cash withdrawals (using automated teller machine-ATMs, for example), and making payment without visiting the bank physically. Though researchers around the world have labeled e-banking in different ways, for example, Keivani et al. (2012) referred to e-banking as personal computer banking, online banking, virtual banking, or Internet banking), they put importance on providing an inclusive concept of electronic banking.

Developments in ICT and its diversified utilization in the banking sector have created a revolution in banking service quality (Mahmoud, 2019). E-banking facilitates banking service channels and information exchanges in a more economical way (Sohail \& Shanmughan, 2003) by lowering the transaction cost (Lin et al., 2005). E-banking helps increase the customer base (Okibo \& Wario, 2014), expand the geographical area of the banks, attract potential customers, and facilitates customer retention (Dandapani et al., 2008). The Basel Committee Report of 2003 on Banking Supervision states that e-banking services should incorporate wholesale, retail, and small to large value banking products in the banking service platform that are to be delivered electronically.

However, e-banking has been recognized as an e-commerce service in the field of banking and financial services (Siddik et al., 2016). Not unlike to the diversified e-commerce offerings, banks can expand their line of products and services to their existing and potential customers through e-banking channels, along with their traditional banking (Sokolov, 2007). However, since the first introduction of the e-banking concept in the mid-1970s in the USA, the system has gone through a drastic change and development in product offerings among which the most popular and common services are automated teller machines (ATMs), electronic cards, mobile banking, SMS banking, and Internet banking.

Compared to the USA or other developed economies, e-banking in Bangladesh is relatively a new phenomenon. The initial or primitive e-banking offerings were introduced by a few private commercial banks, along with the foreign-based commercial banks with online banking, mobile banking, or Internet banking, within a closed network environment (Siddik et al., 2016). At the early stage in e-banking studies in Bangladesh, Al-Amin and Rahman (2010) conceptualized electronic banking as the process of enabling customers easy access to their accounts and helping the receiving banks by provided product updates using a personal computer or other intelligent devices, which is not a true e-banking system. More clearly, the e-banking framework of Bangladesh primarily encompasses online banking, Internet banking, and mobile banking (Siddik et al., 2016), while the most popularly used e-banking forms in Bangladesh are the automated teller machines (ATMs), online banking, and mobile banking.

Therefore, the empirical evidence on e-banking studies from a Bangladesh perspective has documented different concepts of e-banking. Based on the literature review and the technology-based banking practices in Bangladesh, this paper conceptualizes e-banking as the process of providing banking services to the doorsteps of the customers using information communication technology (ICT)-based operations.

\section{Past Studies}

The incredible developments in technology-based innovations and their adoption in organizations have attracted the bulk of researchers' attention around the world (Halawani et al., 2020; Mahmoud, 2019; George, 2018; Egland et al., 1998; Perry, 1988). Similar to the technology usage trend in different organizational settings, the banking sector also adopted and utilized electronic means to 
conduct their banking operations. Therefore, following the increasing technology usage trend in the banking sector and the effects of e-banking on banks' financial performance has widely been examined (Siddik et al., 2016; Akhisar et al., 2015) from different country settings (for example, Yang et al., 2018-China; Siddik et al., 2016-Bangladesh; Al-Smadi \& Al-Wabel, 2011-Jordan; Hernando \& Nieto, 2007-Spain). However, empirical evidence posits different outcomes form different perspectives and country settings. Researchers across countries documented different impacts, for example, positive, negative, and mixed impact of e-banking on a banks' financial performance.

Onay and Ozsoz (2013) administered a study compiling the data of 18 commercial banks in Turkey to investigate the effects of Internet banking adoption on the commercial banks' overall performance. Using panel data regression, they documented a positive impact of Internet banking adoption on branch level operational activities. However, they also demonstrated that Internet banking adoption resulted in low interest income after two years of adoption because of increased competition. Hernando and Nieto (2007) used data from 72 Spanish commercial banks, covering the period of 1994 to 2002, in examining the impact of Internet delivery channel adoption on the financial performance of the selected banks. Their estimations show a positive impact of transactional website adoption on the banks' profitability after a one and a half year time lag. However, they concluded by mentioning the Internet as a complementary means of transacting rather than a substitute for physical branches/ATMs.

Onay et al. (2008) followed an approach similar to Hernando and Nieto (2007) to evaluate the relationship between Internet banking adoption and the performance of commercial banks in Turkey. The empirical results of their study showed that Internet banking has a positive relationship with return on equity (ROE), with a two-year time lag, whereas Internet banking negatively affected the ROE with a one-year time lag. However, they could not document any significant impact of Internet banking on banks' return on assets (ROA) or interest margins. Covering a period of 2003 to 2013, Yang et al. (2018) conducted a study on five commercial banks in China to examine whether electronic banking improved financial performance. They considered ROA, ROE, operating margin (OM), net interest margin (NIM), and efficiency ratio, as measures of a bank's performance, and documented that there was a significant improvement in ROA, ROE, and OM, after electronic banking adoption, but failed to show a significant relationship between e-banking and bank performance with respect to NIM and efficiency ratio.

Rahman (2007) conducted a study examining the relationship between innovative technology usage and bank profitability from Bangladesh's perspective and concluded with positive remarks on the relationship. The positive impact of electronic banking on banks' performance has also been noted in other similar studies (DeYoung et al., 2007; Oyewole et al., 2013; Siddik et al., 2016). Following the studies of Onay et al. (2008), Hernando and Nieto (2007), and Oyewole et al. (2013), a study was conducted by Siddik et al. (2016), which examined the e-banking effects on bank performance from a developing country setting. Using panel data from 13 private commercial banks in Bangladesh, they administered a pooled ordinary least square (OLS) regression estimation covering the period of 2003 to 2013. The findings of the study showed that e-banking had significant impact on return on equity (ROE), with a time lag of two years. The study also revealed an important negative association between e-banking system adoption and ROE in the first year of e-banking adoption. However, the study did not show any significant impact of e-banking on ROA and NIM. DeYoung et al. (2007) studied the impact of Internet banking on a bank's profitability. They identified 424 internet-banks and 5,157 non-Internet banks in the USA, and compared the changes between 1999 and 2001. They examined the banks' profitability in terms of ROA and ROE, where the empirical results found that the bank's profitability could be enhanced by adding the Internet delivery channels. Aduda and Kingoo (2012) added credibility to the findings of DeYoung et al. (2007) by establishing a positive association between electronic banking operations and banks' financial performance. They applied a Pearson Product-Moment Correlation Coefficient test to examine the relationship between e-banking utilization and financial performance of the banks and found a strong and significant effect on Kenyan banks' 
financial performance. A significant positive relationship between e-banking adoption-utilization and bank profitability was also found in the study of Karimzadeh et al. (2014).

One of the early stage e-banking studies was conducted by DeYoung (2001) with a data set of 6 pure-play Internet banks and 522 benchmark banks to draw an identical conclusion about the financial performance of pure-play Internet banks. He documented that pure-play Internet banks observe poor performance in respect to return on assets (ROA) and return on equity (ROE). Siam (2006) examined the impact of electronic banking on the profitability of banks in Jordan. The results of the study showed that e-banking had a negative impact on banks' profitability in the short run, but was positive in the long term. Using an unbalanced panel data of 85 commercial banks in India, Malhotra and Singh (2009) estimated the relationship between e-banking and financial performance. The results of an ordinary least square (OLS) regression revealed that there is no significant relationship between electronic banking adoption and the financial performance of the commercial banks in India. Arnaboldi and Claeys (2010) examined the relationship between innovation adoption and the performance of European banks. The panel data regression from 60 of the largest European banking groups over the period 1995 to 2005 revealed poor performance of Internet banking groups, which is similar to the findings of Delgado et al. (2007) and Al-Smadi and Al-Wabel (2011). A summary of the e-banking studies is presented in Table 1.

Table 1. Summary of e-Banking studies

\begin{tabular}{|c|c|c|c|}
\hline Dependent Variable & Context & Findings & Source \\
\hline PERF & Spain & $\begin{array}{l}\text { Positive impact on banks' profitability } \\
\text { with one and a half year time lag }\end{array}$ & $\begin{array}{l}\text { Hernando and Nieto } \\
\text { (2007) }\end{array}$ \\
\hline PERF (ROE, ROA) & Turkey & $\begin{array}{l}\text { Significant positive impact on ROE } \\
\text { with two year time lag }\end{array}$ & Onay et al. (2008) \\
\hline PERF (interest income) & Turkey & $\begin{array}{l}\text { Overall low interest income after two } \\
\text { years of e-Banking adoption }\end{array}$ & Onay and Ozsoze (2013) \\
\hline $\begin{array}{l}\text { PERF (ROA, ROE, OM, NIM, } \\
\text { efficiency ratio) }\end{array}$ & China & $\begin{array}{l}\text { Significant improvement in ROA, } \\
\text { ROE, and OM after e-Banking } \\
\text { adoption }\end{array}$ & Yang et al. (2018) \\
\hline PERF (ROE, ROA, NIM) & Bangladesh & $\begin{array}{l}\text { Significant positive association } \\
\text { between e-Banking and ROE with a } \\
\text { two year time lag }\end{array}$ & Siddik et al. (2016) \\
\hline PERF (ROA, ROE) & USA & Positive impact on profitability & DeYoung et al. (2007) \\
\hline PERF (ROA) & Kenya & Positive impact on ROA & $\begin{array}{l}\text { Aduda and Kingoo } \\
\text { (2012) }\end{array}$ \\
\hline PERF (ROA) & Iran & $\begin{array}{l}\text { Significant positive association } \\
\text { between e-Banking expansion and } \\
\text { ROA }\end{array}$ & Karimzadeh et al. (2014) \\
\hline PERF (ROA, ROE) & USA & $\begin{array}{l}\text { Poor performance in terms of ROA } \\
\text { and ROE by pure play Internet banks }\end{array}$ & DeYoung (2001) \\
\hline PERF (ROA, ROE) and NPA & India & $\begin{array}{l}\text { No significant relationship between } \\
\text { e-Banking and profitability }\end{array}$ & $\begin{array}{l}\text { Malhotra and Singh } \\
\text { (2009) }\end{array}$ \\
\hline PERF & Europe & $\begin{array}{l}\text { Poor performance by Internet banking } \\
\text { groups }\end{array}$ & $\begin{array}{l}\text { Arnaboldi and Claeys } \\
(2010)\end{array}$ \\
\hline PERF (ROE) & Jordan & $\begin{array}{l}\text { Significant negative impact on banks' } \\
\text { performance (ROE) }\end{array}$ & $\begin{array}{l}\text { Al-Smadi and Al-Wabel } \\
\text { (2011) }\end{array}$ \\
\hline
\end{tabular}

PERF = Performance; ROA = Return on assets; ROE = Return on equity; OM = Operating margin; NIM = Net interest margin; NPA = Nonperforming assets 
In addition to the aforementioned e-banking studies, there are few empirical studies that offer evidence on the performance evaluation of nationalized or government-owned commercial banks from different perspectives. For example, Vidyarthi (2019) examines the relationship between income diversification and firm performance of both private and government-owned commercial banks in India. The author applied tobit regression to analyze the panel data from 38 commercial banks (24 government-owned banks and 14 private commercial banks) listed in the Bombay Stock Exchange, and documented a better performance by private commercial banks than the government-owned commercial banks. Using balanced panel data from 36 commercial banks ( 21 government-owned and 15 private commercial banks), Gupta and Mahakud (2020) assessed CEO characteristics and firm performance.

Behara et al. (2015) examined IT adoption and firm performance using the data from nationalized commercial banks and IT firms. The study reported that early adopters were more beneficiaries than that of late adopters. However, the extant literature failed to provide strong evidence on examining the effect of electronic banking adoption on the performance of nationalized or state-owned commercial banks from the perspective of emerging countries, which provide ample opportunities to address the relationship between e-banking adoption and the financial performance of state-owned commercial banks.

\section{METHODOLOGY}

\section{Sample and Data}

This study selected state-owned commercial banks because they are the largest service providers in the banking sector of Bangladesh. They have the largest branch network across the country and serve the largest number of account holders. The state-owned commercial banks of Bangladesh provide multidimensional services to their clients. The government, therefore, the Bangladesh Bank (The Central Bank of Bangladesh), implements the government monetary policy and regulates the money market of the country through these state-owned commercial banks in Bangladesh. According to Bangladesh Bank (2020), there are six state-owned commercial banks in Bangladesh among which two are the blended version of development and commercial banks. Therefore, this study chose the remaining four state-owned commercial banks to obtain identical insights about and more comparability among the data obtained from the sample banks, since the ownership pattern, governance practice, operation area, and the customer base, of those sample banks are quite similar. For example, in 1972, the sample banks were constituted as nationalized commercial banks under the Bangladesh Bank (Nationalization), President's Order, No. 26, and operated as nationalized commercial banks until 2007. In 2007, three of the sample banks emerged as the Public Limited Company from nationalized commercial banks under the agreements between the Ministry of Finance of the People's Republic of Bangladesh and the Board of Directors of the respective banks, and were registered under the Banking Companies Act 1991 and Act 1994. It is important to note that one of the sample banks emerged as a Public Limited Company in 1986 under a similar agreement. However, the ownership of the sample banks are held by the Government of the People's Republic of Bangladesh and, therefore, the government has supreme control over the sample banks' corporate management, since the government employs the board of directors. Therefore, the state-owned commercial banks considered as the sample firms in this study have a similar legal framework and ownership pattern.

Furthermore, the state-owned commercial banks offer similar products and services to their clients. For instance, in addition to the general commercial banking services, the sample banks provide priority-based banking facilities to farmers, freedom fighters, physically challenged people, and underprivileged people of the country. Interestingly, it is only the state-owned banks that provide the opportunity to open and maintain a bank account with only BDT 10 (equivalent to USD \$0.12) that is designed for, and offered to, the farmers only. It is important to also note that the state-owned 
commercial banks hold the largest branch network and widest customer base in the country, and the branch network of the state-owned commercial banks is dominated by rural branches.

Another interesting and important common phenomenon of this study's sample banks is the timing of large-scale digitalization in their banking system. Though some of the state-owned commercial banks have a very early stage experience of launching computers in their head offices, large- and wide-scale digitalization took place around 2010, after the declaration of the 'Digital Bangladesh' vision by the government. Since the first time adoption of computer and digital technology-based banking operations, the sample banks provide varied electronic technology-enabled banking services to their customers. For example, the sample banks provide real-time online banking to their customers through fully integrated online core banking solutions (CBSs). All of the sample banks have established, sophisticated, and well-equipped data centers in their head offices, along with disaster recovery sites (DRS), which are a true replica of the data centers that have automatic realtime data synchronization capacity. The sample banks offer real-time interbank fund transfers and are connected with significant banking networks, such as the Bangladesh Automated Clearing House (BACH), Bangladesh Electronic Fund Transfer Network (BEFTN), and the Society for Worldwide Inter-Bank Financial Telecommunication (SWIFT). The sample banks provide 24-hour access to customer accounts through their own established ATM booths, as well as through shared networks. Therefore, data on the sample banks utilized in this study encompass similar attributes in terms of ownership, governance, and service offerings, which provide a general grounding and justification for selecting these particular banks as study samples.

This study has compiled the panel data from the selected sample banks covering the period of 2009 to 2018. According to Hasan et al. (2010), banks in Bangladesh began adopting e-banking in 2001. More clearly, the pace of technology adoption at the firm level received a boost after 2009, when the government declared the 'Digital Bangladesh' vision. Therefore, the study encompasses the period between 2009 and 2018, intending to sight the conclusive effects of e-banking adoption on the financial performance of state-owned commercial banks in Bangladesh. The bank-specific financial and non-financial data have been collected from the published annual reports of the respective banks. The researcher collected the annual reports from the official websites and the head offices of the respective banks or from the repository of the stock exchange of Bangladesh. Macroeconomic data was obtained from the Asian Development Bank data sheet (ADB, 2019) and the Bangladesh Economic Review (BER, 2019) published by the Ministry of Finance, Government of the Peoples' Republic of Bangladesh. The e-banking adoption date of the sample banks was collected through personal communication with the IT departments of the respective banks.

Since the compiled data of the four selected banks covers the period of 2009 to 2018, it is, therefore, cross-sectional data by nature. Moreover, the data is time-series data as well, as it covers a range of years. Thus, the data of the study is pooled data. Following the work of Siddik et al. (2016), Oyewole et al. (2013), and Al-Smadi and Al-Wabel (2011), the current study administered the pooled OLS technique to analyze the balanced panel data.

\section{Variables}

\section{Dependent Variables: Profitability Measures}

To examine the effects of e-banking on state-owned commercial banks' financial performance, this study used three proxy variables as performance measurement tools, which have been widely used in prior studies (Robin et al., 2018; Siddik et al., 2016). Many of the previous studies have used return on equity (ROE) as a measure of bank performance (Robin et al., 2018; DeYoung et al., 2007; Hernando\& Nieto, 2007; Siddik et al., 2016; Yang et al., 2018). ROE measures the magnitude of the efficient use of a banks' equity capital (Robin et al., 2018). Therefore, ROE explains how efficiently the bank management is using the equity holders' funds.

Another widely used bank performance measure is return on assets (ROA), which demonstrates the ability of bank management in generating profits on its asset portfolio (Garcia-Meca et al., 2015; 
Pasiouras \& Koksmidou, 2007; Rivard \& Thomas, 1997; Robin et al., 2018; Siddik et al., 2016). To compute the ROA and ROE, this study has used the after-tax net income (Le \& Ngo, 2020; Yang et al., 2018).

In addition to ROA and ROE, scholars have also used net interest margin (NIM) as a measure of bank performance (Le \& Ngo, 2020; Robin et al., 2018; Siddik et al., 2016). Researchers argued that ROE could be increased by many factors, for example, government intervention, which could result in inconsistent results (Onay et al., 2008). Therefore, this study chose NIM as a third measure of firm performance, which would provide a consistent portrayal of bank performance. The concept of NIM depicts that the higher the NIM level, the higher the profitability of the bank.

The net interest margin is the bank's net interest income divided by the total assets of the bank. Here, net interest income is the difference between interest income and interest expenses. Therefore, based on the extant bank performance literature, this study employs all three proxy variables (ROA, ROE, and NIM) as the measurements of bank performance.

\section{Independent Variable}

This study aims to test the implications of electronic banking on banks' profitability; therefore, the independent variable is e-banking. Based on the empirical evidence of Hernando and Nieto (2007) and Siddik et al. (2016), the study developed a dummy variable index, EBANKJ, to examine the effects of e-banking on banks' financial performance. Here, the dummy variable EBANKJ takes the value of one (1) if the bank has introduced e-banking in a particular year $(t)$; otherwise, it takes a value of zero (0). EBANKJ in this study is comprised of EBANK1, EBANK2, and EBANK3, and the co-efficient of these will explain the impact of e-banking on the bank's financial performance.

\section{Control Variables}

To draw a discrete impact of e-banking on bank performance, the study has used several control variables in this study. Bank-specific and country-specific (macroeconomic) determinants are used as control variables that may have an influence on a banks' profitability.

The extant bank performance literature documents a number of bank-specific variables that affect banks' profitability. The capital ratio, therefore, CAP, for this study, has been a widely examined factor in the existing literature (Dietrich \& Wanzenried, 2014; Robin et al., 2018) that might affect the bank profitability. The capital ratio is determined as equity capital divided by total assets, which represents the solvency of a bank. The capital ratio reflects the bank's loss-absorbing capability, which suggests that a bank with a higher capital ratio requires less external funding that results in higher profitability (Kosmidou, 2008; Robin et al., 2018).

The literature on bank performance also suggests that credit risk (CR) has a significant impact on firm profitability (Curak et al., 2012; Le \& Ngo, 2020). Credit risk is measured by the ratio of total non-performing loans to the total loan, which indicates that a bank with a higher CR posits a higher tendency of loss (Siddik et al., 2016). Prior studies also show that asset quality, calculated as the ratio of total loan to total assets (LOANS, in this study) significantly affects a banks' profitability (Garcia-Meca et al., 2015; Maudos et al., 2002; Robin et al., 2018).

Additionally, the literature suggests that a higher loan-to-assets ratio bank is more efficient in transforming its deposit into loans, which, in return, will increase the profits of the bank (Maudos et al., 2002). Firm size (FSZ) is another factor recognized as an important determinant of an organization's profitability in the literature (Garcia-Meca et al., 2015; Robin et al., 2018; Siddik et al., 2016). Not unlike prior studies, this study measures the firm size by the natural logarithm of total assets of the banks. Besides these, corporate governance studies suggest that board independence (BIND) and board size (BSZ) of a bank also affect bank profitability (Dalton et al., 1999; Garcia-Meca et al., 2015; Hermalin \& Weisbach, 1991; Jensen, 1993). 
DeAndres and Vallelado (2008) suggested that board independence might have a significant impact on monitoring the management of the bank. Pathan et al. (2007) documented a significant relationship between board independence and bank profitability. This study measures board independence by the ratio of the number of independent directors on board to the total number of directors on the board. Following the previous studies, this study also considered board size as a significant determinant of a bank's profitability. However, to the knowledge of the researcher, there is no existing empirical evidence on board size impact on a bank's profitability. Board size is measured by the number of members on the board. The capital adequacy ratio (CAR) is another widely tested determinant of a bank's profitability in the past studies (Berger, 1995a, 1995b; Le \& Ngo, 2020). CAR is determined by the ratio of total regulatory capital divided by total risk-weighted assets, as suggested in Basel-III, using two macroeconomic variables, namely the GDP growth rate, and annual inflation rate, to test their effect on banks' profitability (Le \& Ngo, 2020; Robin et al., 2018; Siddik et al., 2016).

Dietrich and Wanzenried $(2011,2014)$ argued that banks' profitability is highly affected by the economic movement of a country. During poor economic conditions, the loan portfolio quality of the banks become worse as a result of credit losses (Athanasoglou et al., 2008; Dietrich and Wanzenried, 2011,2014 . However, there is mixed evidence on the relationship between GDP growth rate (RGDP) and banks' profitability in the literature (Albertazzi \& Gambacorta, 2009; Tan \& Floros, 2012).

The empirical studies on bank profitability have also documented that the inflation rate has a significant impact on banks' financial performance (Bourke, 1989; Dietrich \& Wanzenried, 2011, 2014; Perry, 1992). However, the effect of inflation on bank profitability is theoretically undetermined (Dietrich \& Wanzenried, 2011, 2014). The literature further suggests that the impact of inflation on a bank's financial performance depends on whether the inflation is anticipated or unanticipated (Perry, 1992). A summary of the definition of variables used and their empirical supports are presented in Table 2.

\section{Research Model}

Following the works of Siddik et al. (2016), Onay et al. (2008), Onay and Ozsoz (2013), DeYoung et al. (2001), and Al-Smadi and Al-Wabel (2011), this study has adopted the following empirical model where bank performance (PERFit) is measured by return on assets (ROA), return on equity (ROE), or net interest margin (NIM) for bank $I$ in the year $t$ :

$$
\mathrm{PERF}_{i t}=\alpha_{0+} \theta_{t} \mathrm{MACRO}_{t}+\beta_{t} X_{i t}+\lambda_{i t} \mathrm{EBANK}_{i t}^{j}+\varepsilon_{i t}
$$

Performance of the bank $I$ in the year $t$ is denoted by PERFit in the empirical model. The PERFit has been measured by three proxy variables, viz., ROA, ROE, and NIM. As suggested by Siddik et al. (2016), Onay et al. (2008), and Hernando and Nieto (2007), this study employs EBANKJ as the independent variable, which is the matrix of dummy variables that equals 1 if the bank $I$ adopted e-banking in the year $t$.

Thus, EBANK1 is a dummy variable that takes 1 if the bank adopted e-banking in the year $t$ (that is, during the last one year); EBANK2 takes 1 if the bank adopted e-banking in $t$-1. Similarly, EBANK3 takes 1 if the bank adopted e-banking in $t-2$.

Xit denotes the bank-specific control variables (CAP, CR, LOANS, FSZ, BSZ, BIND, and CAR) matrix for the bank $I$ in the period $t$. Besides this, MACRO $t$ demonstrates the matrix of country-specific macroeconomic control variables (RGDP, INF) in year $t$. eit is a disturbance error term, i.e., eit is independently and identically distributed as $\mathrm{N}(0, \sigma 2)$, and $\alpha 0$ is a bank-fixed effect term that captures time-invariant influence specific to bank $i$. The main focus of the study would be derived by the co-efficient of the variables EBANKJ, while other variables are incorporated as control variables. 
Table 2. Summary of variables used and their specification

\begin{tabular}{|c|c|c|c|c|}
\hline Variable & Descriptions & Legend & $\begin{array}{l}\text { Expected } \\
\text { effect }\end{array}$ & Support \\
\hline Return on assets & $\begin{array}{l}\text { Net profit after tax } \div \text { total } \\
\text { assets }\end{array}$ & ROA & + & Le and Ngo (2020); Yang et al. (2018) \\
\hline $\begin{array}{l}\text { Return on } \\
\text { equity }\end{array}$ & $\begin{array}{l}\text { Net profit after tax } \div \\
\text { equity }\end{array}$ & ROE & + & $\begin{array}{l}\text { Yang et al. (2018); Al-Smadi and Al-Wabel } \\
\text { (2011) }\end{array}$ \\
\hline $\begin{array}{l}\text { Net interest } \\
\text { margin }\end{array}$ & $\begin{array}{l}\text { Net interest income } \div \\
\text { total assets }\end{array}$ & NIM & + & $\begin{array}{l}\text { Siddik et al. (2016); Raharjo et al. (2014); } \\
\text { Robin et al. (2018); Yang et al. (2018); } \\
\text { Oyewole et al. (2013) }\end{array}$ \\
\hline E-banking & $\begin{array}{l}\text { Dummy variable equal } \\
\text { to one if the bank offer } \\
\text { e-Banking and zero } \\
\text { otherwise }\end{array}$ & EBANK & + & $\begin{array}{l}\text { Siddik et al. (2016); Hernando and Nieto } \\
\text { (2007); Onay et al. (2008); Onay and Ozsoz } \\
\text { (2013); Al-Smadi and Al-Wabel (2011); } \\
\text { Oyewole et al. (2013) }\end{array}$ \\
\hline Capital ratio & Equity $\div$ total assets & CAP & + & $\begin{array}{l}\text { Robin et al. (2018); Dietrich and Wanzenried } \\
\text { (2014); Siddik et al. (2016); Oyewole et al. } \\
\text { (2013) }\end{array}$ \\
\hline Credit risk & $\begin{array}{l}\text { Nonperforming loans } \div \\
\text { total loans }\end{array}$ & $\mathrm{CR}$ & - & $\begin{array}{l}\text { Le and Ngo (2020); Curak et al. (2012); } \\
\text { Siddik et al. (2016); }\end{array}$ \\
\hline Loans & Total loans $\div$ total assets & LOANS & + & $\begin{array}{l}\text { Curak et al. (2012); García-Meca et al. } \\
\text { (2015); Robin et al. (2018) }\end{array}$ \\
\hline Firm size & Logarithm of total assets & FSZ & $?$ & $\begin{array}{l}\text { Robin et al. (2018); Curak et al. (2012); } \\
\text { Dietrich and Wanzenried (2014); Siddik et al. } \\
\text { (2016); García-Meca et al. (2015) }\end{array}$ \\
\hline Board size & $\begin{array}{l}\text { Number of board } \\
\text { members }\end{array}$ & BSZ & $?$ & $\begin{array}{l}\text { Shungu et al. (2014); García-Meca et al. } \\
\text { (2015); Morshed et al. (2020) }\end{array}$ \\
\hline $\begin{array}{l}\text { Board } \\
\text { independence }\end{array}$ & $\begin{array}{l}\text { Number of independent } \\
\text { directors on board } \div \\
\text { number of board members }\end{array}$ & BIND & + & $\begin{array}{l}\text { Robin et al. (2018); Morshed et al. (2020); } \\
\text { Shungu et al. (2014); García-Meca et al. } \\
\text { (2015) }\end{array}$ \\
\hline $\begin{array}{l}\text { Capital } \\
\text { adequacy ratio }\end{array}$ & $\begin{array}{l}\text { Total regulatory capital } \div \\
\text { total risk weighted assets }\end{array}$ & CAR & $?$ & $\begin{array}{l}\text { Le and Ngo (2020); Morshed et al. (2020); } \\
\text { Berger (1995); Sharma et al. (2013) }\end{array}$ \\
\hline $\begin{array}{l}\text { Economic } \\
\text { growth }\end{array}$ & GDP growth rate & RGDP & + & $\begin{array}{l}\text { Le and Ngo (2020); Robin et al. (2018); } \\
\text { Curak et al. (2012); Dietrich and Wanzenried } \\
\text { (2014); Siddik et al. (2016) }\end{array}$ \\
\hline Inflation & $\begin{array}{l}\text { Current period inflation } \\
\text { rate }\end{array}$ & INF & + & $\begin{array}{l}\text { Le and Ngo (2020); Robin et al. (2018); } \\
\text { Dietrich and Wanzenried (2014); Siddik et } \\
\text { al. (2016) }\end{array}$ \\
\hline
\end{tabular}

\section{EMPIRICAL RESULTS}

\section{Descriptive Statistics}

Table 3 presents the descriptive statistics of variables (dependent, independent, and control) used in the analysis to provide insights into the variables. Among the dependent variables, ROA has a mean value of $0.21 \%$, having a minimum value of $-4.92 \%$ and a maximum value of $2.04 \%$, with a standard deviation of 0.014 . The variability involved in the values is projected with the standard deviation. A big variability in the values of ROE is seen in the descriptive statistics presented in Table 3. ROE has a mean value of $-5.90 \%$ with the minimum and maximum values of $-259.94 \%$ and $25.73 \%$, respectively. Therefore, it is observed that the state-owned commercial banks have gone through massive fluctuations (50.59\% variability with respect to ROE) throughout the sample period. Table 
Table 3. Descriptive statistics

\begin{tabular}{|l|l|l|l|l|l|}
\hline \multicolumn{1}{|c|}{ Variable } & \multicolumn{1}{c|}{ Obs } & \multicolumn{1}{c|}{ Mean } & \multicolumn{1}{c|}{ Std. Dev. } & \multicolumn{1}{c|}{ Min } & \multicolumn{1}{c|}{ Max } \\
\hline ROA & 40 & 0.0021155 & 0.0138048 & -0.0491676 & 0.0203734 \\
\hline ROE & 40 & -0.0590173 & 0.5058546 & -2.599377 & 0.2573376 \\
\hline NIM & 40 & 0.005463 & 0.0118723 & -0.0143166 & 0.0300116 \\
\hline CAP & 40 & 0.0568891 & 0.0267339 & -0.0637334 & 0.1134953 \\
\hline CR & 40 & 0.1777672 & 0.0856798 & 0.0256 & 0.3528 \\
\hline LOANS & 40 & 0.4981653 & 0.0817408 & 0.3202883 & 0.6538529 \\
\hline FSZ & 40 & 11.67285 & 0.2800698 & 10.94241 & 12.11622 \\
\hline BSZ & 40 & 11.325 & 1.575249 & 8 & 16 \\
\hline BIND & 40 & 0.0109691 & 0.0299198 & 0 & 0.1111111 \\
\hline CAR & 40 & 0.156025 & 0.286443 & -0.868 & 0.947 \\
\hline RGDP & 40 & 0.0646 & 0.0081171 & 0.05 & 0.079 \\
\hline INF & 40 & 0.0712 & 0.0156356 & 0.054 & 0.109 \\
\hline
\end{tabular}

$\mathrm{ROA}=$ Return on assets, $\mathrm{ROE}=$ Return on equity, NIM $=$ Net interest margin, $\mathrm{CAP}=$ Capital ratio, $\mathrm{CR}=$ Credit risk, LOANS $=$ Loans, FSZ = Firm size, $\mathrm{BSZ}=$ Board size, $\mathrm{BIND}=$ Board independence, $\mathrm{CAR}=$ Capital adequacy ratio, $\mathrm{RGDP}=\mathrm{GDP}$ growth rate, INF = Inflation

3 also shows that NIM has a mean value of $0.55 \%$ with a minimum value of $-1.43 \%$ and maximum value of $3 \%$, and a variability of $1.19 \%$. Apart from the dependent variables, Table 3 also presents a different level of variability for each of the explanatory variables used in this study.

\section{Multicollinearity Test}

Following the previous studies, the multicollinearity of the data and variables used in this study are tested using variance inflation factors (VIF) (Chen \& Rothscild, 2010; Siddik et al., 2016), and the correlation matrix (Pawlicz \& Napierala, 2017). The literature suggests that VIF with a value of less than 10 is acceptable (Kennedy, 1985; Lin, 2006; Marquardt, 1980; Siddik et al., 2016). It is also argued that a correlation coefficient at the 0.9 level or higher shows certain multicollinearity between the variables (Dohoo et al., 1997). On the other hand, Chen and Rothschild (2010) argued that there is no absolute rule for the determination of the significance of the multicollinearity phenomenon in a particular regression analysis application. However, the study employed both the variance inflation factor (VIF) and correlation matrix to satisfy the multicollinearity issue. Table 4 shows that the VIF for each of the variables used in the study are much lower than the threshold value 10 . The correlation matrix also proved that there is no issue of multicollinearity in this study. The correlation matrix is shown in the Appendix.

\section{Estimate Results and Discussion}

Table 5 presents the ordinary least squares (OLS) regression results for each of the dependent variables (ROA, ROE, and NIM) on the independent variable (EBANKj) and control variables. The results show that the study model explains $81.17 \%$ of the variations in ROA; $76.21 \%$ of the variations in ROE; and $88.56 \%$ of the variations in NIM. The F-value indicates that the independent variables are significantly related to bank performance.

The empirical results drawn from the pooled OLS regression estimate show that EBANK1 has a significant negative association with ROA and ROE, which is similar to the findings of DeYoung et al. (2001) and Arnaboldi and Claeys (2010). This indicates that, in the first year of e-banking system adoption, the banks faced a fall in their returns. From the study results, it could be surmised that the 
Table 4. Variance inflation factors

\begin{tabular}{|l|l|l|}
\hline \multicolumn{1}{|c|}{ Variable } & \multicolumn{1}{c|}{ VIF } & \multicolumn{1}{c|}{ 1/VIF } \\
\hline CAP & 3.73 & 0.268089 \\
\hline LOANS & 3.15 & 0.317311 \\
\hline BIND & 2.93 & 0.340850 \\
\hline FSZ & 2.72 & 0.368180 \\
\hline CR & 2.57 & 0.388913 \\
\hline BSZ & 1.81 & 0.552530 \\
\hline INFL & 1.74 & 0.574322 \\
\hline GDP & 1.70 & 0.588802 \\
\hline CAR & 1.67 & 0.600132 \\
\hline EBANK1 & 1.47 & 0.681104 \\
\hline EBANK3 & 1.30 & 0.768797 \\
\hline EBANK2 & 1.18 & 0.847430 \\
\hline Mean VIF & 2.16 & \\
\hline
\end{tabular}

Table 5. OLS Estimation Results

\begin{tabular}{|c|c|c|c|c|c|c|c|c|c|}
\hline \multirow{3}{*}{ Variables } & \multicolumn{9}{|c|}{ Dependent variables } \\
\hline & \multicolumn{3}{|c|}{ ROA } & \multicolumn{3}{|c|}{ ROE } & \multicolumn{3}{|c|}{ NIM } \\
\hline & Coef. & $\mathbf{T}$ & $P>t$ & Coef. & $\mathbf{T}$ & $P>t$ & Coef. & $\mathbf{T}$ & $P>t$ \\
\hline EBANK $^{1}$ & -0.0304528 & -6.62 & $0.000 * * *$ & -1.090257 & -5.76 & $0.000 * * *$ & -0.0035277 & -1.14 & 0.262 \\
\hline EBANK $^{2}$ & 0.0087151 & 2.11 & $0.044^{* *}$ & 0.130849 & 0.77 & 0.448 & -0.0018471 & -0.67 & 0.509 \\
\hline EBANK $^{3}$ & -0.0043167 & -1.00 & 0.327 & -.1168368 & -0.66 & 0.518 & -0.0053337 & -1.84 & $0.077 *$ \\
\hline CAP & 0.1999944 & 2.40 & $0.023^{* *}$ & 9.446285 & 2.75 & $0.010^{* * *}$ & 0.2173799 & 3.89 & $0.001 * * *$ \\
\hline $\mathrm{CR}$ & -0.0463493 & -2.15 & $0.041^{* *}$ & -1.2356 & -1.39 & 0.176 & 0.0322019 & 2.23 & $0.034 * *$ \\
\hline LOANS & -0.022729 & -0.91 & 0.372 & -0.6058018 & -0.59 & 0.562 & 0.1059914 & 6.23 & $0.000 * * *$ \\
\hline FSZ & -0.0045341 & -0.67 & 0.510 & 0.036643 & 0.13 & 0.897 & -0.014539 & -3.20 & $0.004 * * *$ \\
\hline BSZ & -0.0007517 & -0.76 & 0.452 & -0.0292608 & -0.72 & 0.477 & -0.0010942 & -1.66 & 0.109 \\
\hline BIND & 0.1346329 & 2.04 & $0.051 * *$ & 4.925181 & 1.81 & $0.081^{*}$ & 0.0297446 & 0.67 & 0.507 \\
\hline CAR & -0.0124189 & -2.39 & $0.024 * *$ & -0.1706381 & -0.80 & 0.432 & -0.011908 & -3.42 & $0.002 * * *$ \\
\hline GDP & -0.3237249 & -1.75 & $0.092 *$ & -7.501138 & -0.98 & 0.334 & -0.0355665 & -0.29 & 0.777 \\
\hline INF & 0.0591568 & 0.61 & 0.548 & 1.697697 & 0.42 & 0.675 & 0.1688158 & 2.59 & $0.015^{* *}$ \\
\hline _cons & 0.091506 & 1.11 & 0.278 & 0.2726008 & 0.08 & 0.937 & 0.1095548 & 1.98 & $0.058^{*}$ \\
\hline \multicolumn{2}{|l|}{ R-squared } & \multicolumn{2}{|l|}{0.8117} & \multicolumn{3}{|l|}{0.7621} & \multicolumn{3}{|l|}{0.8856} \\
\hline \multicolumn{2}{|c|}{ Adj R-squared } & \multicolumn{2}{|c|}{0.7281} & \multicolumn{3}{|l|}{0.6564} & \multicolumn{3}{|l|}{0.8348} \\
\hline \multicolumn{2}{|l|}{ F-Statistic } & \multicolumn{2}{|c|}{$\begin{array}{l}9.70(\mathrm{p} \text {-value }= \\
0.0000)\end{array}$} & \multicolumn{3}{|c|}{$7.21(\mathrm{p}$-value $=0.0000)$} & \multicolumn{3}{|c|}{$17.43(\mathrm{p}$-value $=0.0000)$} \\
\hline
\end{tabular}

Note: ${ }^{* * *},{ }^{* *}$, and ${ }^{*}$ denote statistical significance level at $1 \%, 5 \%$, and $10 \%$ respectively. 
initial adoption of e-banking involves high costs related to necessary digital technology expenses, which may result in reduced returns. Siam (2006) also argued that electronic banking adoption negatively affects firm profitability in the short run.

On the other hand, the OLS regression estimate shows a significant positive relationship between the e-banking and ROA in the following year of e-banking adoption. Therefore, it could be presumed that in the following year of e-banking adoption, after recovering their investments in technologies, the banks began to experience profits. Hernando and Nieto (2007) also find a positive association between e-banking and a firm's profitability under a one and one-half year time lag. However, in terms of NIM, there was a continuous adverse impact of e-banking, though not significant in the e-banking adoption year and in the following year of adoption. Further, in the third year of e-banking adoption, the current research observes a negative association between e-banking system adoption and banks' profitability again. Among the three proxies of bank performance, the regression results also show a significant negative impact of e-banking on the net interest margin. Thus, the results of this study indicate that the banks actually could not make a worthy return in respect to the investments in e-banking system implementation.

In addition to the effects of e-banking on banks' financial performance, the control variables used in this study also show a significant association with firm performance. The regression results show that capital ratio (CAP) has a significant positive impact on bank profitability. The study also projects a positive association among board independence (BIND), inflation (INF), and bank profitability, with respect to all of the three proxy variables. However, the OLS estimate shows that credit risk (CR) has a significant negative impact on ROA, but a positive association with NIM. The loan-to-assets ratio (LOANS) also has a positive and significant relationship with NIM. This suggests that banks can earn more interest income with a high level of loans and advances issued to customers. On the other hand, the study results also show that a high level of non-performing loans would reduce the actual return.

Therefore, bank management should concentrate on enhancing sound loan profile and reducing bad loans. This study notes a negative relationship between bank size and profitability, which suggests that large banks are generating fewer profits. Apart from the finance-related variables, corporate governance (CG) related variables (BSZ, BIND, and CAR) also show an important association with banks' profitability. The panel data estimate shows a strong positive relationship between board independence (BIND) and banks' profitability with respect to ROA and ROE. This implies that independent directors on the board play a vital role in assuring a bank's returns. Besides all these bank-specific control variables, the macroeconomic control variables (GDP and INF) also show a significant impact on banks' profitability. The analysis suggests that GDP growth negatively affects the state-owned commercial banks' returns, while the inflation rate has a positive association with the banks' profitability.

Therefore, the findings suggest that the state-owned commercial banks of Bangladesh fail to capitalize on the benefits of innovations, and thus their efforts resulted in negative returns due to the adoption of electronic banking systems.

\section{CONCLUSION}

Financial institutions, especially banks, play a key role in the economic development of emerging economies, such as Bangladesh. Governments around the world, and more particularly, in developing countries, implement their monetary and fiscal policies and control the money market and the velocity of money through their banks, wherein state-owned commercial banks lead the entire operations of the governments. To ensure robust economic growth, enhance managerial and operational efficiency, and increase the productivity of the financial sectors, technology-based innovations are being largely adopted and implemented throughout the world. Since its early introduction and implementation during the mid-1970s in the USA and in some European countries, e-banking has achieved wide popularity and acceptability worldwide. Bangladesh, as other parts of the world, is embracing the 
substantial change in technology-based banking operations, and has widely adopted the e-banking system in the recent past to enhance the efficiency, productivity, and profitability of the banks. Thus, considering the global phenomena, this study examined the impact of information communication technology-based banking operations, namely e-banking systems, on state-owned commercial banks' financial performance. This is, however, to the best of the researcher's knowledge, the first-ever study to investigate the e-banking effects on state-owned commercial banks' financial performance in Bangladesh.

This study used panel data from four state-owned commercial banks in Bangladesh that had adopted e-banking systems during the period of 2009 to 2018. The empirical results of the study confirm that electronic banking has significant impact on state-owned commercial banks' financial performance as a measure in terms of ROA, ROE, and NIM. The use of these three proxies for performance measurement provides a comprehensive outline of banks' financial performance. The study results suggest a strong negative association between e-banking and bank performance, conferring the results of DeYoung et al. (2001), Arnaboldi and Claeys (2010), Al-Smadi and AlWabel (2011).

However, most of the prior e-banking studies have applied a single measure of bank performance (Al-Smadi \& Al-Wabel, 2011; Curak et al., 2012; Shungu et al., 2014), while this study includes three proxies (ROA, ROE, and NIM) to measure the profitability of the state-owned commercial banks, which provides comprehensive insights into the sample banks' performance. One of the key distinctiveness of this study is the attempt to understand the relationship between e-banking system adoption and the financial performance of state-owned commercial banks, as the e-banking literature shows studies relating to private commercial banks. Another important uniqueness of this study is to consider the corporate governance-related control variables along with the bank-specific financial structure-related control variables and country-specific control variables. Therefore, this study is able to present a comprehensive picture of e-banking effects on state-owned commercial banks' financial performance.

The empirical findings, however, of this study differ from some of the prior e-banking studies (Hernando and Nieto, 2007; Yang et al., 2018) since the study result projects a significant negative association between e-banking and the profitability of the sample banks. It is noted that the findings of this study also differ from the findings of Rahman, (2007) and Siddik et al. (2016), although the country perspectives of these studies are same. However, there is a major difference in the samples utilized in the prior studies and those used in the current study, as the prior studies are based on the datasets of private commercial banks and the current study examines the e-banking adoption effects on the performance of state-owned commercial banks in Bangladesh. In practice, there are differences in objectives, operations, management, and governance, between private commercial banks and the state-owned commercial banks operating in Bangladesh. The state-owned commercial banks have a wide range of branch activity across the country, which led to a huge investment in technologybased operations. Moreover, the state-owned commercial banks are rural and branch dominated, since their primary aim is to provide banking services into the homes of the people to implement various government plans, policies, financial strategies, and social services. Thus, the state-owned commercial banks enjoy less freedom to emphasize or implement profit-oriented branch operations only, which frequently results in poor financial performance of the state-owned commercial banks.

In addition to the operational challenges, there are difficulties in the process of adoption and sound implementation of e-banking systems in Bangladesh. For instance, developing countries, such as Bangladesh, suffer from poor IT infrastructure, limited technical expertise, legacy, traditional control systems, poor compatibility, expensive system up-gradations, high maintenance costs, network downtimes, trust, confidentiality, and security concerns, in adopting and implementing e-banking systems. It is important to mention that in February 2016, the Bangladesh Bank, the central bank of Bangladesh, was the victim of a major cyber heist, wherein $\$ 81$ million was lost from its foreign exchange reserve account with the Federal Reserve System of the USA. Recently, the Bangladesh 
Bank warned the banks in Bangladesh to take the necessary measures to prevent future cyber-attacks. As a result, the banks in Bangladesh restricted ATMs, bankcards, and online transactions to avoid risks, which limited banking services to their customers.

In addition to the international cyber-attacks, domestic hackers also disrupt banking operations and often hack into a bank's system stealing the money of their customers which, eventually weakens customer trust and results in poor customer satisfaction and loyalty.

Apart from the common global threats, the state-owned commercial banks in Bangladesh also face problems that include their less motivated employees holding traditional attitudes and legacy, having a huge, uneducated, customer base, and a rural branch network dominance to implement dedicated electronic banking systems. Thus, the state-owned banks often fail to establish comprehensive e-banking system-based operations, therefore, fail to produce optimum outcomes from the technologybased e-banking system adoption.

However, from the findings of the study, it is evident that the state-owned commercial banks in Bangladesh could not capitalize on the benefits of ICT-based e-banking operations compared to their counterparts (private commercial banks). Although the adoption of e-banking is relatively a new phenomenon in Bangladesh, there are differences in the effects of e-banking with respect to private and state-owned commercial banks. In Bangladesh, the private sector commercial banks are the pioneers in adopting e-banking systems, thus, they created tough competition for the late adopters (the state-owned commercial banks). Therefore, to enjoy the ample benefits of e-banking system adoption, the state-owned commercial banks should concentrate on developing a comprehensive security system through the establishment of a security operation center (SOC) to attain the trust of their customers by reducing their security concerns and risks. Additionally, the state-owned banks should emphasize staff development through training, to provide better services to their customers. The banks should also focus on awareness development among their customers, employees, and other stakeholders to avoid risks and fraud, and on establishing a better bank-customer relationship through quality and secured banking services. Further, policymakers and bank management needs to focus on business plans and strategies to mitigate the challenges that have arisen from the competition, poor governance, and high credit risk, to enjoy the enormous benefits of digital technology-based e-banking systems adoption.

Finally, although the current study found a significant association between e-banking system adoption and the profitability of the state-owned commercial banks, the study lacks an inclusive database for all banks in Bangladesh. Therefore, further studies might be initiated on the same issue covering a comprehensive data set from both the private and state-owned commercial banks operating in Bangladesh to confirm and complement the findings of this study. 


\section{REFERENCES}

ADB. (2019). Key Indicators for Asia and the Pacific 2019. Asian Development Bank Data Sheet. https://www. adb.org/publications/key-indicators-asia-and-pacific-2019

Aduda, J., \& Kingoo, N. (2012). The relationship between electronic banking and financial performance among commercial banks in Kenya. Journal of Finance and Investment Analysis, 1(3), 99-118.

Ahmed, F., \& Islam, M. T. (2008). E-banking: Performance, problems and potentials in Bangladesh. Business Review (Federal Reserve Bank of Philadelphia), 6(1), 20-28.

Akhisar, İ., Tunay, K. B., \& Tunay, N. (2015). The effects of innovations on bank performance: The case of electronic banking services. Procedia: Social and Behavioral Sciences, 195, 369-375. doi:10.1016/j. sbspro.2015.06.336

Al-Amin, S., \& Rahman, S. S. (2010). Application of electronic banking in Bangladesh: An overview. Bangladesh Research Publication Journal, 4(2), 172-184.

Al-Omoush, K. S., Al Attar, M. K., Saleh, I. H., \& Alsmadi, A. A. (2020). The drivers of E-banking entrepreneurship: An empirical study. International Journal of Bank Marketing, 38(2), 485-500. doi:10.1108/ IJBM-03-2019-0113

Al-Smadi, M. O., \& Al-Wabel, S. A. (1970). The impact of e-banking on the performance of Jordanian banks. Journal of Internet Banking and Commerce, 16(2), 1-10.

Al-Swidi, A. K., \& Al-Hosam, A. (2012). The effect of entrepreneurial orientation on the organizational performance: A study on the Islamic banks in Yemen using the partial least squares approach. [Oman Chapter]. Arabian Journal of Business and Management Review, 2(1), 73-84. doi:10.12816/0002244

Albertazzi, U., \& Gambacorta, L. (2009). Bank profitability and the business cycle. Journal of Financial Stability, 5(4), 393-409. doi:10.1016/j.jfs.2008.10.002

Aliyu, A. A., \& Tasmin, R. (2012). The impact of information and communication technology on banks' performance and customer service delivery in the banking industry. International Journal of Latest Trends Finance and Economy, 2(1), 80-90.

Ananth, S., \& Singh, C. (2016). Creating an enabling digital ecosystem: issues and challenges in financial inclusion. IIMB Management Review, Working Paper.

Arnaboldi, F., \& Claeys, P. (2010). Innovation and performance of European banks adopting Internet. Academic Press.

Ashraf, M. A., Alam, M. M., \& Noor, M. S. (2020). The Influence of Privacy and Trust on the Adoption of Internet Banking in Bangladesh. Malaysian Management Journal, 14, 33-48. doi:10.32890/mmj.14.2010.8965

Athanasoglou, P. P., Brissimis, S. N., \& Delis, M. D. (2008). Bank-specific, industry-specific and macroeconomic determinants of bank profitability. Journal of International Financial Markets, Institutions and Money, 18(2), 121-136. doi:10.1016/j.intfin.2006.07.001

Azam, M. S. (2014). Diffusion of ICT and SME Performance: the mediating effects of integration and utilization (Doctoral dissertation). Curtin University.

Bangladesh Bank. (2020). Financial System Overview. https://www.bb.org.bd/en/ index.php/financialactivity/ bankfi

Bauer, H. H., Hammerschmidt, M., \& Falk, T. (2005). Measuring the quality of e-banking portals. International Journal of Bank Marketing, 23(2), 153-175. doi:10.1108/02652320510584395

Behera, A., Nayak, N., \& Das, H. (2015). Performance measurement due to IT adoption. Business Process Management Journal, 21(4), 888-907. doi:10.1108/BPMJ-07-2014-0068

BER. (2019). Bangladesh Economic Review. https://mof.gov.bd/site/page/ 44e399b3-d378-41aa-86ff8c4277eb0990/BangladeshEconomicReview 
Berger, A. N. (1995a). The profit-structure relationship in banking—-Tests of market-power and efficient-structure hypotheses. Journal of Money, Credit and Banking, 27(2), 404-431. doi:10.2307/2077876

Berger, A. N. (1995b). The relationship between capital and earnings in banking. Journal of Money, Credit and Banking, 27(2), 432-456. doi:10.2307/2077877

Bourke, P. (1989). Concentration and other determinants of bank profitability in Europe, North America and Australia. Journal of Banking \& Finance, 13(1), 65-79. doi:10.1016/0378-4266(89)90020-4

Chege, S. M., Wang, D., \& Suntu, S. L. (2020). Impact of information technology innovation on firm performance in Kenya. Information Technology for Development, 26(2), 316-345. doi:10.1080/02681102.2019.1573717

Chen, C. F., \& Rothschild, R. (2010). An application of hedonic pricing analysis to the case of hotel rooms in Taipei. Tourism Economics, 16(3), 685-694. doi:10.5367/000000010792278310

Curak, M., Poposki, K., \& Pepur, S. (2012). Profitability determinants of the Macedonian banking sector in changing environment. Procedia: Social and Behavioral Sciences, 44, 406-416. doi:10.1016/j.sbspro.2012.05.045

Dalton, D. R., Daily, C. M., Johnson, J. L., \& Ellstrand, A. E. (1999). Number of directors and financial performance: A meta-analysis. Academy of Management Journal, 42(6), 674-686. doi:10.2307/256988

Dandapani, K., Karels, G. V., \& Lawrence, E. R. (2008). Internet banking services and credit union performance. Managerial Finance, 34(6), 437-446. doi:10.1108/03074350810872804

Daniel, E. (1999). Provision of electronic banking in the UK and the Republic of Ireland. International Journal of Bank Marketing, 17(2), 72-83. doi:10.1108/02652329910258934

DeAndres, P., \& Vallelado, E. (2008). Corporate governance in banking: The role of the board of directors. Journal of Banking \& Finance, 32(12), 2570-2580. doi:. 05.00810.1016/j.jbankfin.2008

Delgado, J., Hernando, I., \& Nieto, M. J. (2007). Do European primarily Internet banks show scale and experience efficiencies? European Financial Management, 13(4), 643-671. doi:10.1111/j.1468-036X.2007.00377.x

DeYoung, R., Lang, W. W., \& Nolle, D. L. (2007). How the Internet affects output and performance at community banks. Journal of Banking \& Finance, 31(4), 1033-1060. doi:.jbankfin.2006.10.00310.1016/j

Dietrich, A., \& Wanzenried, G. (2011). Determinants of bank profitability before and during the crisis: Evidence from Switzerland. Journal of International Financial Markets, Institutions and Money, 21(3), 307-327. doi:10.1016/j.intfin.2010.11.002

Dietrich, A., \& Wanzenried, G. (2014). The determinants of commercial banking profitability in low-, middle-, and high-income countries. The Quarterly Review of Economics and Finance, 54(3), 337-354. doi:10.1016/j. qref.2014.03.001

Dohoo, I. R., Ducrot, C., Fourichon, C., Donald, A., \& Hurnik, D. (1997). An overview of techniques for dealing with large numbers of independent variables in epidemiologic studies. Preventive Veterinary Medicine, 29(3), 221-239. doi:10.1016/S0167-5877(96)01074-4 PMID:9234406

Egland, K. L., Gurst, K., Nolle, D. E., \& Robertson, D. (1998). Special Studies on Technology and Banking: Banking over the Internet. Quarterly Journal, 17, 25-30.

Gafoor, C. A., Mariappan, V., \& Thyagarajan, S. (2018). Board characteristics and bank performance in India. IIMB Management Review, 30(2), 160-167. doi:10.1016/j.iimb.2018.01.007

García-Meca, E., García-Sánchez, I.-M., \& Martínez-Ferrero, J. (2015). Board diversity and its effects on bank performance: An international analysis. Journal of Banking \& Finance, 53, 202-214. doi:10.1016/j. jbankfin.2014.12.002

George, A. (2018). Perceptions of Internet banking users-A structural equation modelling (SEM) approach. IIMB Management Review, 30(4), 357-368. doi:10.1016/j.iimb.2018.05.007

Gupta, N., \& Mahakud, J. (2020). CEO characteristics and bank performance: Evidence from India. Managerial Auditing Journal, 35(8), 1057-1093. doi:10.1108/MAJ-03-2019-2224 
Halawani, F. M., Soh, P. C., \& Halawani, Y. M. (2020). The Effects of Social Commerce Utilization on Business Performance: A Study of Hotels in Lebanon. Information Resources Management Journal, 33(3), 1-23. doi:10.4018/IRMJ.2020070101

Hasan, A. S., Baten, M. A., Kamil, A. A., \& Parveen, S. (2010). Adoption of e-banking in Bangladesh: An exploratory study. African Journal of Business Management, 4(13), 2718-2727.

Hernando, I., \& Nieto, M. J. (2007). Is the Internet delivery channel changing banks' performance? The case of Spanish banks. Journal of Banking \& Finance, 31(4), 1083-1099. doi:10.1016/j.jbankfin.2006.10.011

Hossain, M. I., \& Azam, M. S. (2019). Towards e-Governance: An Exploratory Analysis of e-Tax Filing Adoption in Bangladesh. Journal of Business Studies, 12(1), 1-17.

Hsu, W. C., Chen, P. H., \& Chen, C. Y. (2020). An Exploration of the Impact of Virtual Reality Interfaces on Online Shopping. Information Resources Management Journal, 33(2), 19-39. doi:10.4018/IRMJ.2020040102

Jahan, N., Ali, M. J., \& Asheq, A. A. (2020). Examining the key determinants of customer satisfaction internet banking services in Bangladesh. Academy of Strategic Management Journal, 19(1), 1-6.

Jensen, M. C. (1993). The modern industrial revolution, exit, and the failure of internal control systems. The Journal of Finance, 48(3), 831-880. doi:10.1111/j.1540-6261.1993.tb04022.x

Karimzadeh, D., Emadzadeh, D., \& Shateri, J. (2014). The effects of electronic banking expansion on profitability of a commercial bank (Sepah bank of Iran). Indian Journal of Scientific Research, 4(6), 305-312.

Keivani, F. S., Jouzbarkand, M., Khodadadi, M., \& Sourkouhi, Z. K. (2012). A General View on the E-banking. International Proceedings of Economics Development and Research, 43, 62.

Kennedy, P. (1985). A Guide to Econometrics (2nd ed.). Blackwell.

Kondabagil, J. (2007). Risk management in electronic banking: Concepts and best practices (Vol. 454). John Wiley \& Sons. doi:10.1002/9781118390436

Kosmidou, K. (2008). The determinants of banks' profits in Greece during the period of EU financial integration. Managerial Finance, 34(3), 146-159. doi:10.1108/03074350810848036

Le, T. D. Q., \& Ngo, T. (2020). The determinants of bank profitability: A cross-country analysis. Central Bank Review, 20(2), 65-73. 10.1016/j.cbrev.2020.04.001

Lin, F. J. (2006). Solving multicollinearity in the process of fitting regression model using the nested estimate procedure. Quality \& Quantity, 42(3), 417-426. doi:10.1007/s11135-006-9055-1

Lin, J. C., Hu, J. L., \& Sung, K. L. (2005). The effect of electronic banking on the cost efficiency of commercial banks: An empirical study. International Journal of Management, 22(4), 605.

Mahmoud, M. A. (2019). Gender, E-Banking, and Customer Retention. Journal of Global Marketing, 32(4), 269-287. doi:10.1080/08911762.2018.1513108

Malhotra, P., \& Singh, B. (2009). The impact of internet banking on bank performance and risk: The Indian experience. Eurasian Journal of Business and Economics, 2(4), 43-62.

Marquardt, D. W. (1980). Comment: You should standardize the predictor variables in your regression models. Journal of the American Statistical Association, 75(369), 87-91. doi:10.1080/01621459.1980.10477430

Maudos, J., Pastor, J. M., Pérez, F., \& Quesada, J. (2002). Cost and profit efficiency in European banks. Journal of International Financial Markets, Institutions and Money, 12(1), 33-58. doi:10.1016/S1042-4431(01)00051-8

Mohammad Azizul, B., \& Anton Abdulbasah, K. (2010). E-Banking of economical prospects in Bangladesh. $J I B C, 15(2), 1$.

Okibo, B. W., \& Wario, A. Y. (2014). Effects of e-Banking on growth of customer base in Kenyan banks. The International Journal of Management Science and Information Technology, (11), 48-64.

Onay, C., \& Ozsoz, E. (2013). The impact of internet-banking on brick and mortar branches: The case of Turkey. Journal of Financial Services Research, 44(2), 187-204. doi:10.1007/s10693-011-0124-9 
Onay, C., Ozsoz, E., \& Helvacioğlu, A. P. D. A. D. (2008, June). The impact of internet-banking on bank profitability-The case of Turkey. 2008 Oxford Business \&Economics Conference Program.

Oyewole, O. S., Abba, M., Gambo, J., \& Abam, I. (2013). E-banking and bank performance: Evidence from Nigeria. International Journal of Scientific Engineering and Technology, 2(8), 766-771.

Pasiouras, F., \& Kosmidou, K. (2007). Factors influencing the profitability of domestic and foreign commercial banks in the European Union. Research in International Business and Finance, 21(2), 222-237. doi:10.1016/j. ribaf.2006.03.007

Pathan, S., Skully, M., \& Wickramanayake, J. (2007). Board size, independence and performance: An analysis of Thai banks. Asia-Pacific Financial Markets, 14(3), 211-227. doi:10.1007/s10690-007-9060-y

Pawlicz, A., \& Napierala, T. (2017). The determinants of hotel room rates: An analysis of the hotel industry in Warsaw, Poland. International Journal of Contemporary Hospitality Management, 29(1), 571-588. doi:10.1108/ IJCHM-12-2015-0694

Perry, P. (1992). Do banks gain or lose from inflation? Journal of Retail Banking, 14(2), 25.

Perry, T. S. (1988). Electronic banking goes to market. IEEE SPEC, 25(2), 46-49. doi:10.1109/6.4510

Rahman, M., Tazim, M. Z., Das, S., \& Islam, L. (2020 April). State of the art of Mobile Banking Services and Future Prospects in Developing Countries. In 2020 IEEE 9th International Conference on Communication Systems and Network Technologies (CSNT) (pp. 145-149). IEEE.

Rahman, M. M. (2007). Innovative technology and bank profitability: The Bangladesh experience. Policy Analysis Unit (PAU). Bangladesh Bank WP, 803, 1-42.

Rivard, R. J., \& Thomas, C. R. (1997). The effect of interstate banking on large bank holding company profitability and risk. Journal of Economics and Business, 49(1), 61-76. doi:10.1016/S0148-6195(96)00041-0

Robin, I., Salim, R., \& Bloch, H. (2018). Financial performance of commercial banks in the post-reform era: Further evidence from Bangladesh. Economic Analysis and Policy, 58, 43-54. doi:10.1016/j.eap.2018.01.001

Salehi, M., \& Alipour, M. (2010). E-Banking in emerging economy: Empirical evidence of Iran. International Journal of Economics and Finance, 2(1). Advance online publication. doi:10.5539/ijef.v2n1p201

Shungu, P., Ngirande, H., \& Ndlovu, G. (2014). Impact of corporate governance on the performance of commercial banks in Zimbabwe. Mediterranean Journal of Social Sciences, 5(15), 93-93. doi:10.5901/mjss.2014.v5n15p93

Siam, A. Z. (2006). Role of the electronic banking services on the profits of Jordanian banks. American Journal of Applied Sciences, 3(9), 1999-2004. doi:10.3844/ajassp.2006.1999.2004

Siddik, M. N. A., Sun, G., Kabiraj, S., Shanmugan, J., \& Yanjuan, C. (2016). Impacts of e-banking on performance of banks in a developing economy: Empirical evidence from Bangladesh. Journal of Business Economics and Management, 17(6), 1066-1080. doi:10.3846/16111699.2015.1068219

Sivathanu, B. (2019). An Empirical Study on the Intention to Use Open Banking in India. Information Resources Management Journal, 32(3), 27-47. doi:10.4018/IRMJ.2019070102

Sohail, M. S., \& Shanmugham, B. (2003). E-banking and customer preferences in Malaysia: An empirical investigation. Information Sciences, 150(3-4), 207-217. doi:10.1016/S0020-0255(02)00378-X

Sokolov, D. (2007). E-banking: risk management practices of the Estonian banks. Institute of Economics at Tallinn University of Technology, 101.

Tan, Y., \& Floros, C. (2012). Bank profitability and GDP growth in China: A note. Journal of Chinese Economic and Business Studies, 10(3), 267-273. doi:10.1080/14765284.2012.703541

Vidyarthi, H. (2019). Dynamics of income diversification and bank performance in India. Journal of Financial Economic Policy, 12(3), 383-407. doi:10.1108/JFEP-05-2019-0084

Yang, S., Li, Z., Ma, Y., \& Chen, X. (2018). Does electronic banking really improve bank performance? Evidence in China. International Journal of Economics and Finance, 10(2), 82-94. doi:10.5539/ijef.v10n2p82 


\section{APPENDIX}

Figure 1.

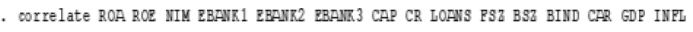

$(\mathrm{obs}=40)$

\begin{tabular}{|c|c|c|c|c|c|c|c|c|c|c|c|c|c|c|c|}
\hline & $\mathrm{BOA}$ & $\mathrm{ROE}$ & NIM & ZBAMR 1 & EBAMK2 & EBAMR3 & $C A P$ & $C R$ & LOANS & FSZ & BSZ & BIND & $C A R$ & GDP & INPL \\
\hline$B O A$ & 1.0000 & & & & & & & & & & & & & & \\
\hline $\mathrm{ROR}$ & 0.9013 & 1.0000 & & & & & & & & & & & & & \\
\hline WIM & 0.1514 & -0.0002 & 1.0000 & & & & & & & & & & & & \\
\hline ZBANR1 & -0.7447 & -0.7632 & 0.1988 & 1.0000 & & & & & & & & & & & \\
\hline EBANR2 & 0.2407 & 0.1539 & -0.0786 & -0.1111 & 1.0000 & & & & & & & & & & \\
\hline ZBANR3 & 0.0609 & 0.0865 & -0.2348 & -0.1111 & -0.1111 & 1.0000 & & & & & & & & & \\
\hline CAP & 0.2465 & 0.4151 & 0.0256 & -0.1246 & 0.1328 & 0.1061 & 1.0000 & & & & & & & & \\
\hline $\mathrm{CR}$ & -0.3722 & -0.3167 & -0.4406 & 0.1048 & 0.1263 & -0.0846 & -0.2829 & 1.0000 & & & & & & & \\
\hline LOPIS & -0.0212 & -0.1432 & 0.7825 & 0.2060 & -0.1251 & -0.1556 & -0.2073 & -0.5639 & 1.0000 & & & & & & \\
\hline PSZ & -0.1639 & 0.0155 & -0.6696 & -0.1104 & -0.0323 & 0.0322 & 0.1709 & 0.3010 & -0.5724 & 1.0000 & & & & & \\
\hline BSZ & 0.0541 & 0.0267 & 0.2449 & 0.0375 & 0.1982 & 0.1982 & 0.2358 & -0.0872 & 0.2558 & -0.3629 & 1.0000 & & & & \\
\hline BIND & 0.0714 & -0.0165 & 0.0644 & -0.1238 & -0.1238 & 0.0525 & -0.6163 & 0.1221 & 0.2117 & -0.3813 & 0.0169 & 1.0000 & & & \\
\hline CAR & -0.0115 & 0.1984 & -0.2218 & -0.1594 & 0.1294 & $-0.056 B$ & 0.4772 & 0.0153 & -0.1478 & 0.0341 & 0.1939 & -0.0898 & 1.0000 & & \\
\hline$G D P$ & -0.2009 & -0.0257 & -0.2747 & -0.0250 & -0.0769 & -0.0561 & 0.1192 & 0.0777 & -0.1657 & 0.4323 & -0.2844 & 0.0671 & 0.1918 & 1.0000 & \\
\hline INFL & -0.0839 & -0.1555 & 0.5278 & 0.3843 & 0.0119 & -0.0637 & 0.1873 & -0.1416 & 0.2481 & -0.3302 & 0.3200 & -0.2433 & -0.1284 & -0.2806 & 1.0000 \\
\hline
\end{tabular}

Md. Imran Hossain is an Assistant Professor in the Department of Accounting and Information Systems, University of Rajshahi. His research interests are in innovation adoption and implications, firm performance analysis, structural equation modeling, and panel data analysis. 